\title{
Dos ketubbot castellanas y otro fragmento hebreo del Archivo de la Real Chancillería de Valladolid
}

\author{
Ricardo Muñoz Solla* \\ Universidad de Salamanca
}

Edición, descripción formal y estudio de tres fragmentos manuscritos hebreos pertenecientes a la colección de Pergaminos del Archivo de la Real Chancillería de Valladolid. Se trata, en concreto, de una hoja de un códice bíblico y dos fragmentos de ketubbot castellanas, hasta ahora inéditas, procedentes de Valencia de Don Juan (León) y Villadiego (Burgos). La existencia de estas piezas se justifica a la luz del proceso de formación y organización de la colección de Pergaminos. El autor ofrece una edición del texto hebreoarameo de las dos ketubbot, destacando su relevancia dentro del conjunto de documentos judíos de carácter matrimonial ya conocidos. Asimismo, reconstruye el contexto particular en el que una de ellas fue producida y reutilizada por sus propietarios. Todo ello puede contribuir a un mejor conocimiento de este tipo de documentos legales en el ámbito del derecho matrimonial hispano-judío medieval.

Palabras Clave: historia de los judíos; Edad Media; Ketubbot; manuscritos hebreos; matrimonio judío; conversos; Valladolid; Valencia de Don Juan; Villadiego; códice bíblico.

Two Castilian Ketubbot and Another Hebrew fragment in the Real Chancillería DE VALLADOLID - Edition, formal description and analysis of three Hebrew fragments belonging to the parchments' collection in the Real Chancillería de Valladolid archives. The fragments published here are a leaf of a Biblical codex and two hitherto unpublished Castilian ketubbot from Valencia de Don Juan (León) and Villadiego (Burgos). These fragments were recovered as a result of the formation and organization of the parchments' collection. The author provides an edition of the original (Hebrew-Aramaic) text of the ketubbot and highlights its importance within the whole corpus of Jewish marriage documents from medieval Castile. Moreover, he provides with additional data for contextualizing the particular context in which one of the ketubbot was produced and reused by its owners. All this may contribute to a better understanding of Hispano-Jewish medieval marriage documents.

KeYwords: History of the Jews; Middle Ages; Ketubbot; Hebrew Manuscripts; Jewish Marriage; Conversos; Valladolid; Valencia de Don Juan; Villadiego; Biblical Codex.

\footnotetext{
"solla@usal.es
} 
De extraordinaria importancia tanto por su riqueza como por la variedad documental que ofrece del periodo medieval hispánico, la colección de Pergaminos de la Real Chancillería de Valladolid se creó en 1975 como una serie facticia que se ha ido formando con documentos y fragmentos de códices encontrados durante el proceso de catalogación y revisión de los legajos de las distintas secciones que conforman el Archivo'. Desde entonces, los pergaminos que se iban localizando se han incorporado a esta serie. En la actualidad, en la base de datos de esta colección se contabiliza un total de 4.325 regis$\operatorname{tros}^{2}$. Su digitalización concluyó en 2007. La serie se ha considerado prácticamente cerrada desde 1985; y, aunque cabe la posibilidad de que se produzcan nuevos hallazgos, no es previsible que estos puedan modificarla sustancialmente.

Una temprana descripción de esta colección fue realizada por la antigua directora del Archivo, $M^{a}$. S. Arribas González $z^{3}$. Con posterioridad, miembros de la Cátedra de Paleografía de la Universidad de Valladolid y de Burgos han dedicado un notable esfuerzo a la transcripción, edición y estudio de un gran número de estos pergaminos. En brillante síntesis, J. Ma . Ruiz Asencio ofrecía las claves necesarias para entender el origen y formación de esta colección que está formada por dos secciones: la de documentos y la de fragmentos de códices u hojas sueltas.

a) Los documentos (en su mayor parte originales, pero también en forma de confirmaciones y traslados) fueron aducidos como elementos

\footnotetext{
${ }^{1}$ Estructurada en cuatro salas: Sala de lo Civil, Sala de lo Criminal, Sala de Hijosdalgo y Sala de Vizcaya. Para una descripción más detallada de estas secciones y su formación, vid. M. S. Martín Postigo, Historia del Archivo de la Real Chancillería de Valladolid (Valladolid, 1979); C. EMPERAdor Ortega, «El Archivo de la Real Chancillería de Valladolid. Los documentos de un antiguo tribunal de Justicia», en Valladolid, ciudad de Archivos, ed. S. Arribas Carnicer - A. Marcos Martín (Valladolid, 2011), 99-138.

${ }^{2}$ La sección está formada por 95 cajas (con 1010 unidades documentales) y 210 carpetas (3315 unidades documentales). Una descripción actualizada del fondo puede consultarse en línea en: http://pares.mcu.es/ParesBusquedas/servlets/Control_servlet?accion=3\&txt_ id_desc_ud $=184152 \&$ fromagenda $=\mathrm{N}$ [última consulta: $20 / 01 / 2014$ ].

3 «Algunos pergaminos medievales del Archivo de la Real Chancillería de Valladolid», Hidalguía 214-215 (1989), 325-336.

${ }^{4}$ «La colección de fragmentos latinos de la Chancillería de Valladolid», en Actas del II Congreso Hispánico de Latín Medieval, ed. M. Pérez GonzÁLEz (León, 1998), 175-185.
} 
de prueba en los pleitos civiles, criminales y de hidalguía que se siguieron en la Chancillería vallisoletana. Tanto en los pleitos que se vieron en primera instancia (casos de Corte), como en los que se siguieron en caso de apelación, estos documentos probatorios se incorporaron en el expediente del pleito sin que, en muchos casos, fueran recuperados por la institución o persona que los aportó. En este caso, la procedencia del pergamino puede determinarse con relativa facilidad, ya que en el pleito de referencia se suele encontrar información sobre las partes pleiteantes que aportaron la prueba así como la localidad de procedencia.

La tipología de los documentos conservados es muy variada: cartas y traslados de donación, mercedes reales, privilegios rodados, cartas de fuero, cartas plomadas, títulos, cartas de testamentos, ejecutorias de hidalguías, diplomas, cartas pontificias, etc. En ocasiones, estos constituyen un unicum, otras veces son copias simples; también menudean algunas falsificaciones. Las principales aportaciones hasta el momento se han centrado en la edición de los diplomas altomedievales y otros documentos de temprana datación y características paleográficas singulares ${ }^{5}$.

b) Los fragmentos de códices u hojas sueltas fueron utilizados habitualmente como soportes de encuadernación. A finales del siglo XV, y ante la difusión de la imprenta y del libro impreso, muchos códices de pergamino viejo pasaron a ser de poca utilidad y fueron reutilizados (íntegra o fragmentariamente) por los escribanos de la Chancillería para conservar sus procesos o como guardas de sus libros y escrituras notariales. Fue una práctica común a raíz de la pragmática del 7 de julio de 1503 en la que se obligaba a los escribanos públicos a conservar bien encuadernados todos sus protocolos y entregarlos sin deterioro a su sucesor en la notaría ${ }^{6}$. En estos casos, dada su dispersión, es difícil concretar su procedencia $u$ ofrecer una identificación completa de su contenido.

${ }^{5}$ Vid. M. Herrero JimÉnez, «Documentos de la colección de Pergaminos del Archivo de la Real Chancillería de Valladolid (934-1300)», en El Reino de León en la Edad Media XI (León, 2004), 11-240.

${ }^{6}$ Vid. A. Riesco Terrero, «El notariado castellano bajomedieval, s. XIV-XV: Historia de esta institución y de la producción documental de los notarios hasta Isabel I de Castilla», en II Jornadas cientificas sobre documentación de la Corona de Castilla (siglos XIII-XV), ed. J. C. Galende Díaz (Madrid, 2003), 175-225: 217. 
En su inmensa mayoría, esta sección está formada por hojas sueltas de libros litúrgicos: fragmentos de misales, misales-breviarios, biblias y comentarios bíblicos, evangeliarios, pasionarios y cantorales. En menor medida, se conservan también fragmentos de obras de derecho, fundamentalmente canónico y civil, así como de obras teológicas, de vida y regla monásticas, de carácter filosófico o literario ${ }^{7}$.

La variedad y posibilidades de estudio paleográfico, histórico y filológico que ofrece la colección de Pergaminos es de gran valor para investigadores y estudiosos de disciplinas muy diversas. Este carácter misceláneo me llevó a considerar la posibilidad de localizar nuevos manuscritos hebreos durante el proceso de actualización de este fondo que se ha realizado durante la última década. Como es bien sabido, muchos de los pleitos civiles y cartas ejecutorias conservados en este Archivo aportan, directa o indirectamente, noticias muy precisas sobre el pasado judío de muchos territorios castellanos situados al norte de la línea del Tajo, que fue el límite natural que marcaba la jurisdicción de la Chancillería vallisoletana ${ }^{8}$ Pero, en

\footnotetext{
${ }^{7}$ Para una bibliografía más específica sobre las características de estos fragmentos vid. RuIZ AsENCIO, «La colección de fragmentos latinos de la Chancillería de Valladolid», 184, así como la reciente aportación de I. RUIZ ALBI, «Un fragmento de los Bocados de Oro en el Archivo de la Real Chancillería de Valladolid», en Alma Litera: Estudios dedicados al profesor José Manuel Ruiz Asencio, ed. M. HerRero de LA Fuente et alii (Valladolid, 2014), 579-594.

${ }^{8}$ Desde las primeras noticias ofrecidas por Fritz Baer, son numerosas las aportaciones que tienen como base documentación relativa a judíos procedente de este archivo, cuyo estudio sistemático ya plantearon F. Cantera Burgos y C. Carrete Parrondo. Sin ánimo de ser exhaustivos, vid. Ma . A. VARONA GarCíA, «Judíos y moros ante la justicia de los Reyes Católicos. Cartas Ejecutorias de la Real Chancillería de Valladolid (1476-1494)», en Proyección histórica de España en sus tres culturas. Castilla y León, América y el Mediterráneo, coord. E. LoRENZO SAINZ (Valladolid, 1993), I, 337-368, y «Pleitos de judíos en la Real Chancillería de Valladolid. Regesta de sus cartas ejecutorias (1486-1495)», Sefarad 54 (1994) 155-193; C. CARRETE PARrondo - Y. Moreno KoCH, «Conflicto jurídico en la judería de Ávila (1487)», en Judaísmo Hispánico. Estudios en Memoria a José Luis Lacave, ed. E. Romero (Madrid, 2002), II, 679687; Ma. F. GARCIA CASAR «Tensiones internas de las aljamas castellanas», en Movimientos migratorios y expulsiones en la diáspora occidental. Terceros Encuentros Judaicos de Tudela, ed. J. CARRASCO (Pamplona, 2000), 69-78; R. MuÑOZ SollA, «Nuevas noticias sobre la sinagoga mayor de León», Estudios Mirandeses, 25 (2005), 131-149; IDEM, «El destino de la sinagoga de Burgos después de 1492», Boletín de la Institución Fernán González 234 (2007), 87-121, y 235 (2007), 337-375; IDEM, "Padrones y antroponimia judía en el Condado de Treviño en el siglo XV», Hispania Judaica Bulletin 9 (2013), 97-130; J. CASTaÑo- S. DEL Rey Granell, «Judíos y
} 
contraste con este material, redactado en romance y escritura cortesana, hay que asumir que la documentación en hebreo o en aljamía hebrea resulta muy escasa y, en todo caso, poco significativa en relación con el conjunto total de documentos que se conservan.

En 1980 se publicaba póstumamente un artículo de F. Cantera Burgos en el que se estudiaba una selección de una treintena de cédulas y recibos emitidos a los judíos de la aljama de Amusco (Palencia) que contenían anotaciones contables en aljamía hebraico-castellana realizadas por el mayordomo judío del Duque de Nájera, Rabí Yuçé Milano. En el pleito iniciado a instancia de Isaac Mordohay, en nombre de la aljama de los judíos de Amusco, se pedía a los vecinos y alcaldes mayores que no molestasen ni perturbasen a los judíos durante los tres meses de plazo que tenían para salir del Reino, de modo que pudieran resolver los pleitos pendientes entre cristianos y judíos y hacer liquidación de cuentas entre ambos ${ }^{9}$.

Hasta ahora el único contrato matrimonial judío que se había encontrado en la Sección de Pergaminos era la ketubbá de Torrelobatón (Valladolid), fechada en el mes de marzo de $1480^{10}$. Los trabajos de M $^{\mathrm{a}}$. F. García Casar ${ }^{11}$, J. L. Lacave ${ }^{12}$ y A. Represa ${ }^{13}$ son suficientemente conocidos por lo que no me detendré en ellos, salvo las

redes personales en Tierra de Campos durante la segunda mitad del siglo XV: un Cuaderno de Minutas de Avecindamientos de Villalón», Sefarad 69 (2009), 361-382; E. DE LA PeÑa BARroso, Los judios de Medina del Campo a finales del siglo XV (Valladolid, 2009).

${ }^{9}$ ARChV, Pleitos Civiles, Fernando Alonso (F), Caja 540/7, en tres piezas. Vid. F. Cantera Burgos, «La administración judía del Duque de Nájera en la aljama palentina de Amusco», en Hommage à Georges Vajda: études d'histoire et de pensée juives, eds. G. NAHON - Ch. TouATI (Louvain, 1980), 309-321.

${ }^{10}$ ARChV, Pergaminos, Carpeta 13/11. Pleito de Referencia: Sala de lo Civil, Quevedo (F), Caja 1412/4. Se trata de la carta de esponsales entre Nuño de la Torre y Mencía Velázquez, judíos conversos, antes llamados Rabí Mosé Amigo y Bienvenida.

${ }^{11}$ «Algunas precisiones sobre la ketubbah de Torre Lobatón», en Encuentros en Sefarad, eds. F. Ruiz Gómez - M. Espadas Burgos (Ciudad Real, 1987), 41-43.

${ }_{12}$ J. L. Lacave, Medieval Ketubot from Sefarad (Jerusalem, 2002), 29, 72-73, 247 251 y 299.

13 «Una carta de esponsales y otras prescripciones sobre el matrimonio entre judíos y conversos castellanos», en Encuentros en Sefarad, eds. F. Ruiz GómEZ - M. Espadas Burgos (Ciudad Real, 1987), 33-39. 
alusiones pertinentes que se realicen a lo largo de este trabajo. Este estudio pretende complementar estos trabajos previos con la descripción detallada de tres nuevos fragmentos manuscritos hebreos recientemente localizados ${ }^{14}$. Se trata, en concreto, de un fragmento de códice bíblico y de dos ketubbot de origen castellano.

\section{Un FRAGMENTO DE UN CÓDICE BÍBLICO}

El fragmento bíblico conservado ${ }^{15}$ es una hoja opistográfica de un códice bíblico ( 320 × $280 \mathrm{~mm}$ ), caja de escritura con 28 líneas (250 x $197 \mathrm{~mm})$ a doble columna (250 x $85 \mathrm{~mm})$, escritura cuadrada sefardí (siglo XV) con vocalización y acentuación tiberienses en tinta sepia y buen estado de conservación. Sin foliación, fecha ni referencia de procedencia, no tiene vinculación con los manuscritos hebreos conservados en la Biblioteca Universitaria de Santa Cruz de Valladolid $^{16}$.

El pergamino es de fina factura; el lado de la carne corresponde al recto y el lado del pelo al vuelto. Presenta marcas irregulares de haber sido cortado en su margen derecho y marca de doblez en su parte central. Se observan líneas de pautado verticales de justificación simples $(1+2+1)$ con 28 líneas horizontales de trazado largo, a punta seca, realizada sobre el lado de la carne, sin marcas de punteado. Las verticales se han reforzado con mina de plomo.

Su contenido reproduce casi en su totalidad tres capítulos del libro de Éxodo (שמות): Ex 1:16 - Ex 3:15 (nacimiento y juventud de Moisés, huída a Madián y manifestación en la zarza ardiente), pertenecientes a la $12^{\text {a }}$ perícopa del ciclo anual o parašat Šemot (Ex 1:1-6:1) según la siguiente distribución:

${ }^{14}$ Las primeras noticias sobre su existencia y contenido las ofrecí en la comunicación presentada en la Sección de Hebreo y Arameo del Congreso Internacional EOS700. Séptimo Centenario de los Estudios Orientales en Salamanca, celebrado en Salamanca los días 28-30 de septiembre de 2011.

${ }^{15}$ ARChV, Pergaminos, Carpeta 1/22.

${ }^{16}$ Vid. F. Cantera Burgos, «Más sobre los manuscritos hebreos de la Biblioteca de Santa Cruz en la Universidad de Valladolid», Sefarad 14 (1959), 223-240. 
fol. $1 r$

Columna a: Desde segundo hemistiquio de Ex 1:16 hasta primer hemistiquio de Ex 2:8

Columna $b$ : Desde segundo hemistiquio de Ex 2:8 hasta Ex 2:20

fol. $1 v$

Columna a: Desde Ex 2:21 hasta Ex 3:7

Columna b: Desde Ex 3:7 hasta Ex 3:15

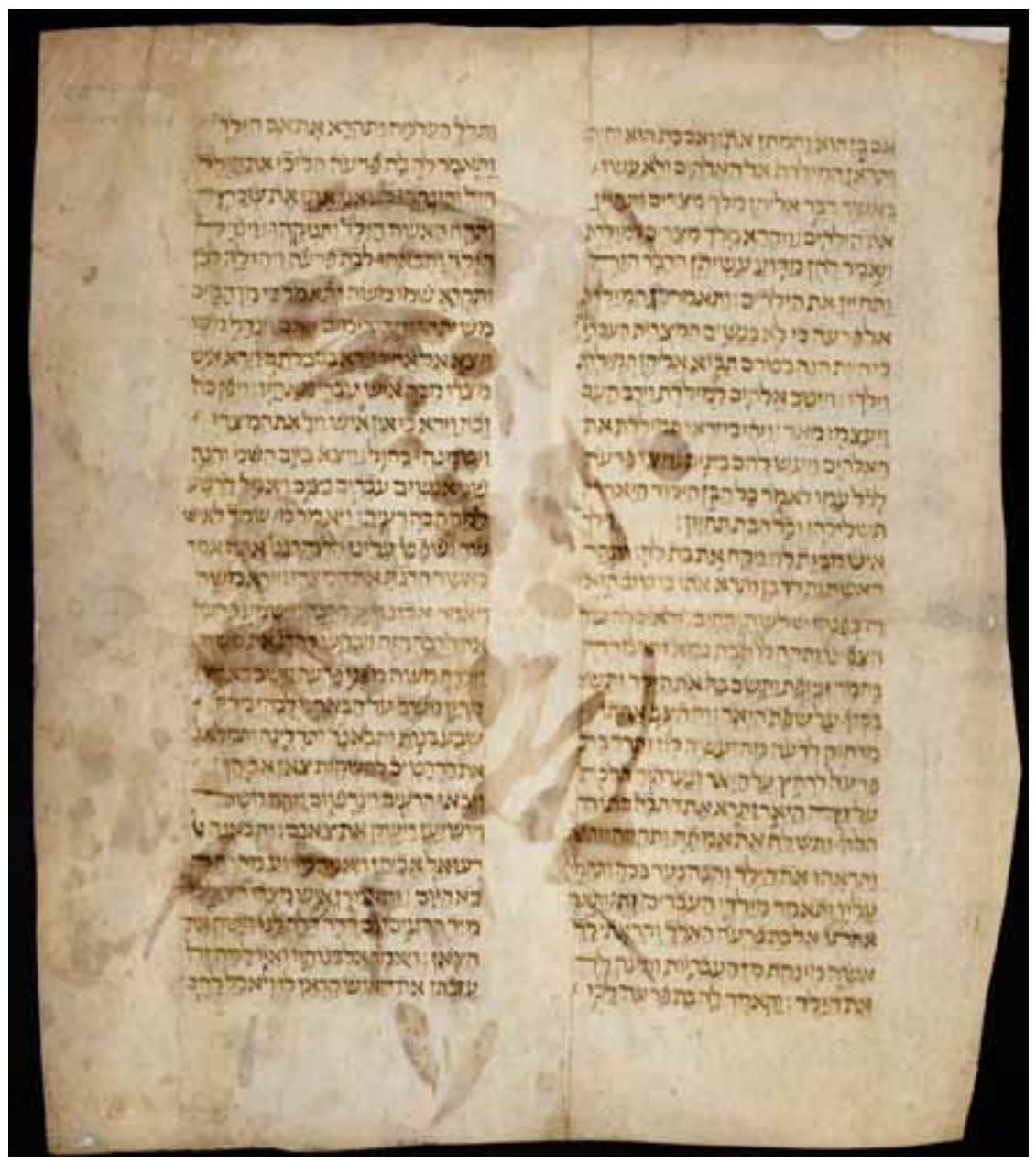

Fig. 1a. Hoja de códice bíblico, s.d.

(C) ARChV, Pergaminos, Carpeta 1/22, fol. r 


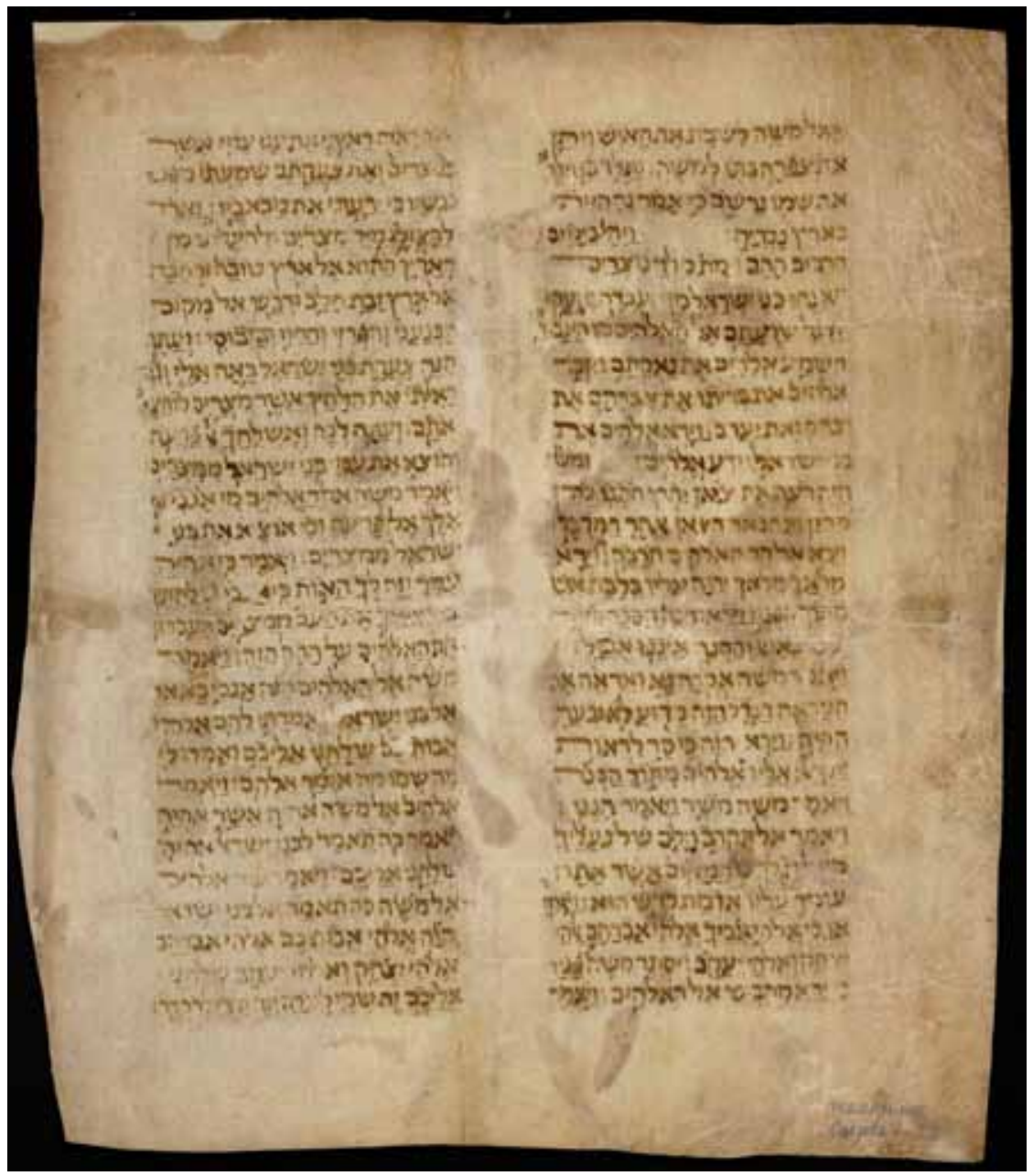

Fig. 1b. Hoja de códice bíblico, s.d.

(C) ARChV, Pergaminos, Carpeta 1/22, fol. v

En líneas generales, la copia es fiel al texto masorético, con presencia de acentos conjuntivos y disyuntivos (salvo casos de deterioro de la tinta) e indicación de rafé. Carece de masora magna y de masora parva en los márgenes y no parece haberse trazado pautado para ellas. Se respetan tanto las secciones cerradas o setumot (סתומות), que se distinguen en Ex 
1:22 (fol. 1r, col. a, 1. 13), y Ex 2:25 (fol. 1v, col. a, 1. 11) como las cerradas o petuhot (פתוחות) en Ex 2:22 (fol. 1v, col. a, 1. 4) pero ninguna de ellas está indicada mediante abreviación ${ }^{17}$. Se observa alguna corrección (zeh, fol. 1r, col. a, 1. 25; Yśra'el, fol. 1v, col. b, 1.11), prolongación de letras al final de línea (fol. 1r, col. a, 1. 27; fol. 1r, col. b, 1. 3, 4, 22; fol. $1 v$, col. a, 1. 5, 10, 19, 20) así como añadidos de letras fuera de la caja de escritura (fol. 1r, col. a, 1. 7, 8, 23, 24; fol. 1v, col. a, 1. 2, 7, 11, 25).

\section{Contratos matrimoniales o KetubBot}

El contrato matrimonial (̌̌ețar ketubbá) es un tipo documental del que apenas se han conservado restos materiales en el reino de Castilla. De las treinta y dos ketubbot editadas por Lacave tan solo cuatro, todas ellas datadas en el siglo XV, proceden de territorios castellanos: la ya mencionada ketubbá de Torrelobatón, la de Segura de León (Badajoz), Alba de Tormes (Salamanca) y Trijueque (Guadalajara). Cabe añadir, además, una ketubbá procedente de Zamora, también del siglo XV, muy deteriorada que, junto con la de Segura de León, se conserva en la Biblioteca Nacional de Israel ${ }^{18}$. La escasez de ketubbot castellanas, en relación con las procedentes de Aragón y Navarra (tampoco excesivamente numerosas $)^{19}$ ofrece una notable dificultad a la hora de establecer una tipología exacta de sus rasgos formales y de contenido. La perspectiva

${ }^{17}$ Vid. D. Stern, «Una introducción a la historia de la Biblia hebrea en Sefarad», en Biblias de Sefarad / Bibles of Sepharad, eds. E. Alfonso - J. DEL BARCO - Ma. T. Ortega Monasterio - A. Prats (Madrid, 2012), 49-85: 59.

${ }^{18}$ Vid. LaCaVe, Medieval Ketubot, 70-74. Ambas pueden consultarse en el siguiente link: http://dlib.nli.org.i1/R/KJ3LSFXV1CQFJNLCE79P88XJ84A1HT3CYYX5ET11GLKH XSUTGQ-11516?func=collections\&collection_id=17451 [última consulta: 01/02/2014].

${ }^{19}$ Según la estadística ofrecida por Lacave, Medieval Ketubot, 9-12, doce proceden de Cataluña, cuatro de Mallorca y nueve de Navarra. A este elenco habría que añadir el artículo (con traducción al castellano de la ketubbá) de J. R. MAGDALENA-M. Blasco, «Una ketubbá inédita catalana de Santa Coloma de Montbui (s. XIV)», en Judaísmo Hispánico. Estudios en Memoria a José Luis Lacave, ed. E. Romero (Madrid, 2002), II, 575-584; así como los hallazgos más recientes aportados por M. PerANI, «The Gerona Genizah: an Overview and a Rediscovered Ketubah of 1377», Hispania Judaica Bulletin 7 (2010), 137-173, y J. CASTAÑo, «Ketubbot en-cubiertas: fuentes para el estudio del matrimonio judío en Jaca y los Almosnino», Sefarad 69 (2009), 43-73. 
comparativa utilizada por Lacave en su estudio conjunto de las ketubbot conservadas supuso un extraordinario avance en la comprensión de estos documentos como textos jurídicos hispano-hebreos muy estandarizados, pero lo cierto es que, su escasa representatividad numérica, no permite ofrecer conclusiones definitivas en cuanto al uso de determinadas fórmulas o en lo que respecta a una tipología específica siguiendo criterios geográficos o distintas costumbres locales. Cabe preguntarse por el motivo de esta ausencia material, si se tiene en cuenta que el matrimonio representó para las comunidades judías hispánicas la forma más habitual de reconocimiento social para el proyecto familiar que se iniciaba con la firma de una ketubbá, ya que en ella se estipulaba el régimen económico de ambas partes con el objeto de salvaguardar fundamentalmente la posición de la mujer judía. Además de las irremediables pérdidas materiales provocadas por el paso del tiempo, es verosímil pensar que muchos de los judíos expulsados en 1492 llevaran consigo, junto a otras pertenencias, las pruebas y condiciones escritas de su unión matrimonial; estas podrían garantizar a las mujeres sus derechos conyugales ante las autoridades judías de las comunidades en las que se asentaron, sobre todo, en casos de divorcio o viudedad. Según la ley rabínica, la ketubbá era la que legitimizaba la vida conyugal y debía de estar en posesión de la mujer. Si esta la perdía, incluso se podía redactar una nueva (aram. ketubbá de-'irkesá') ${ }^{20}$. Las dos ketubbot que se editan en este estudio permite incrementar el número de las conocidas hasta ahora pero habrá que esperar a futuros hallazgos para poder comprender muchos otros detalles de esta interesante manifestación del derecho matrimonial hispanojudío.

\subsection{Ketubbá de Valencia de Don Juan (León)}

\section{a) Descripción y contenido}

Este fragmento de ketubbá $(397 \text { x } 245 \mathrm{~mm})^{21}$, en buen estado de conservación, presenta muestras de haber sido recortado en su parte superior e inferior así como en el margen lateral izquierdo, con marcas

${ }^{20}$ TB, Ketubbot 56a; R. Yosef Caro, Šulhán 'Aruk , 'Eben ha- 'Ezer 66:3.

${ }^{21}$ ARChV, Pergaminos, Carpeta 190/2. 
de encuadernación. Escrito en su totalidad en escritura semicursiva sefardí del siglo XV, se distinguen dos párrafos independientes separados por un amplio espacio en blanco en el que se insertan dos rúbricas. En los márgenes laterales, en escritura cuadrada de mayor tamaño y sin decoración ornamental, se citan como preámbulo versículos del libro de Rut. En el dorso del pergamino se conserva una anotación en castellano y escritura cortesana fechada en Valladolid el 26 de marzo de 1501. Se trata de una diligencia formal de petición de testigos que no está relacionada con el contenido de la ketubbá, pero que hace alusión a las partes demandantes del pleito de referencia, al que luego aludiré.

A continuación se presenta la transcripción anotada de este fragmento $^{22}$. Dado que más adelante se ofrecerá una traducción parcial del texto en castellano medieval, he prescindido de incluir otra actualizada al español; salvo los contenidos concretos que se analizarán, la redacción y fórmulas de matrimonio no difieren de otras ketubbot ya conocidas, y a ellas me remito $^{23}$.

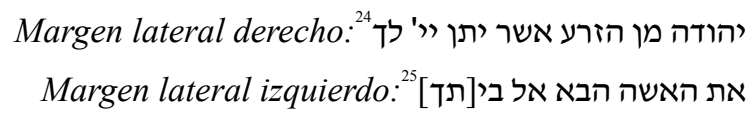

${ }^{22}$ Dispuesto en 28 líneas. En la transcripción se indican mediante subíndice. Las abreviaturas se desarrollan en nota a pie de página. Utilizo [ ] para indicar adición, [...] para texto ilegible y [?] para lectura dudosa.

${ }^{23}$ Vid. Lacave, Medieval Ketubot, 247-251; IDEM, Los judios del Reino de Navarra. Documentos Hebreos, 1297-1486 (Pamplona, 1998).

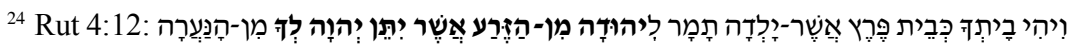
הַזּאָת ('Y por la posteridad que Adonay te conceda de esta joven sea tu casa como la casa de Pereș, el que Tamar parió a Judá').

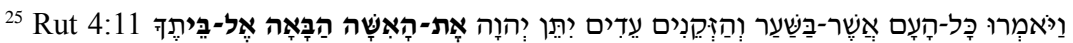
'Y todo el pueblo que estaba en la Puerta y los ancianos dijeron: ¡Testigos somos! Adonay haga a la mujer que va a entrar en tu casa semejante a Raquel y a Lía, las cuales dos han edificado la casa de Israel! ¡Adquiere poderío en 'Efratá, y cobra nombradía en Belén!’). 


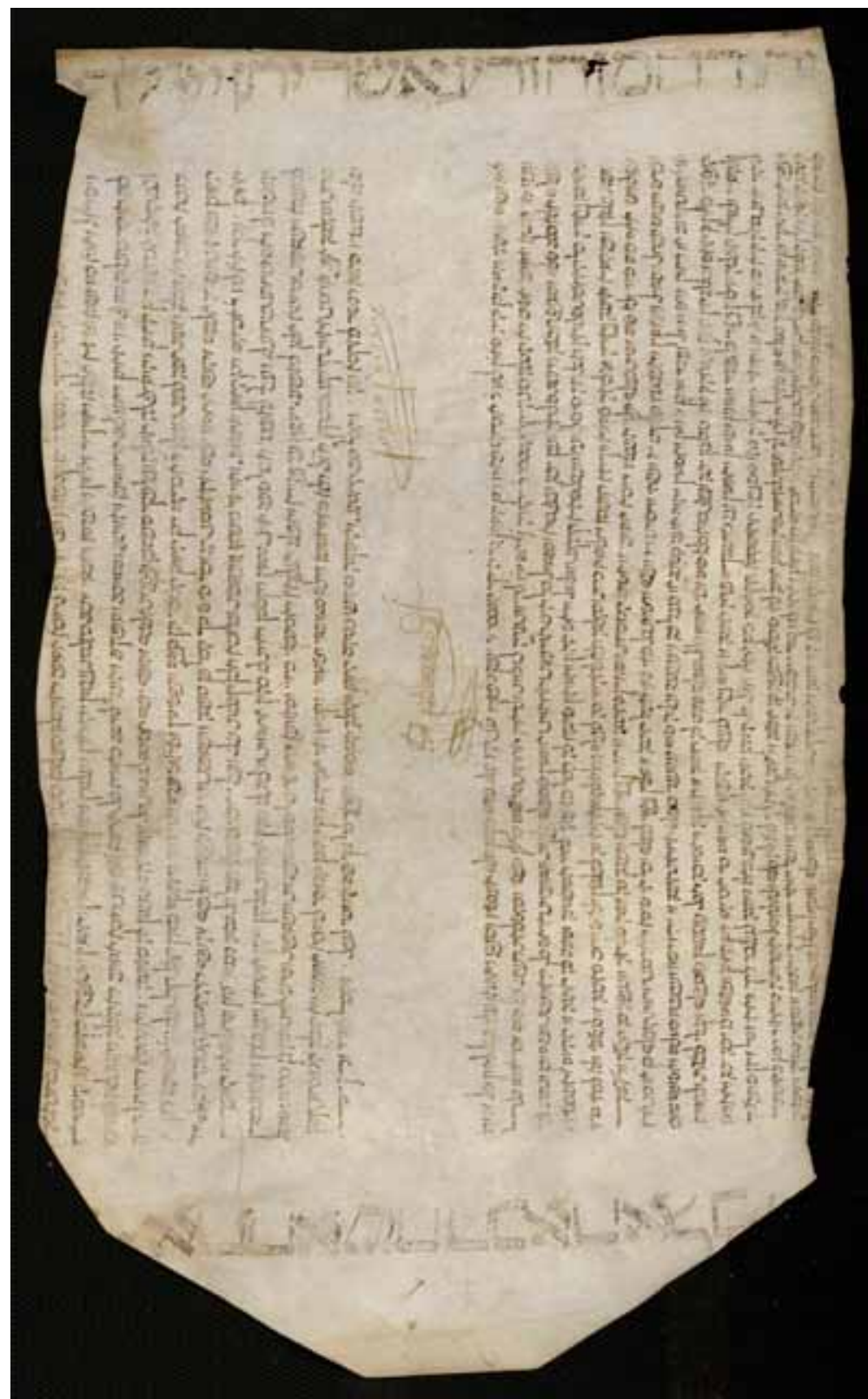

Fig. 2. Fragmento de Ketubbá, $2^{\mathrm{a}}$ mitad siglo XV. Valencia de Don Juan (León) (C) ARChV, Pergaminos, Carpeta 190/2 
[אברהם] פ'ארו ${ }^{26}$ בר היקר הנכבד ר' יעקב פ'ארו נ"עי אמ']ר] לה לדוניא אסתר דא הכלה

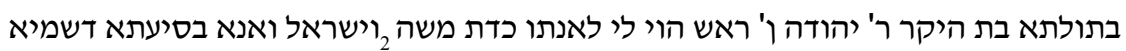

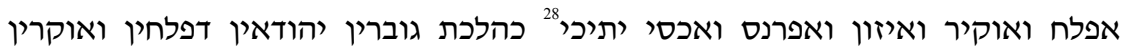

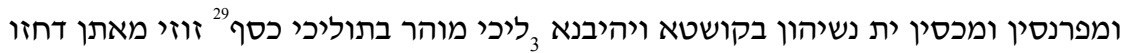
ליכי מדאוריתא ומזוניכי וכסותיכי וספוקיכי ומעל לותיכי כאורח כל ארעא וצביאת דוניא

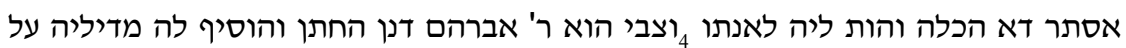

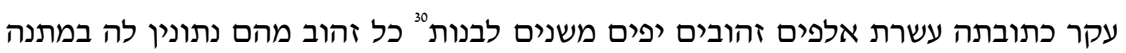

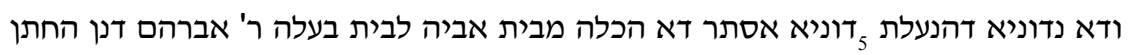
הנזכר הן בגדים ותכשיטין ושמוש ערס וכל דבר דמתקרי נכסין הכל קבל עליו ר' אברהם דנן

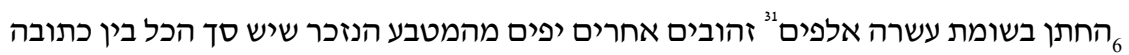

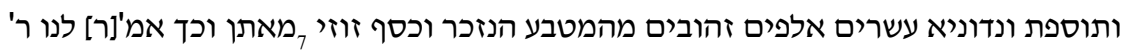

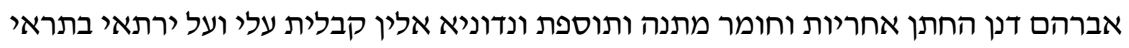

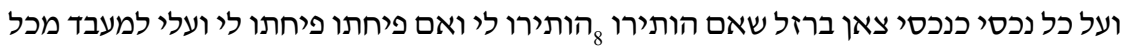
שפר ארג נכסין וקנינין דאית לי בהון אחריות ודלית לי בהון אחריות כלהון יהון אחראין

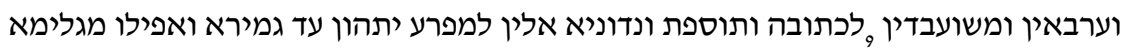

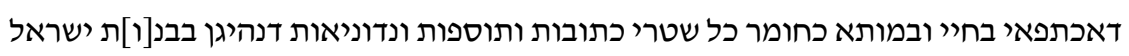

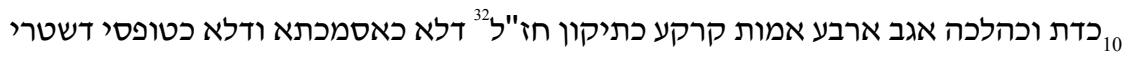

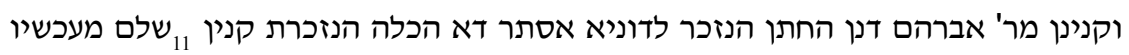

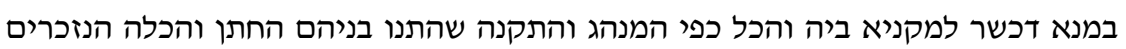

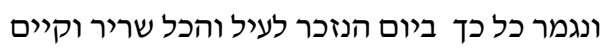

${ }^{26}$ Nótese el uso del rafé para la fricativa פ.

${ }^{27}$ Heb. נשמתו עדן, 'su alma descanse en el Edén'.

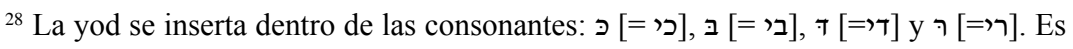

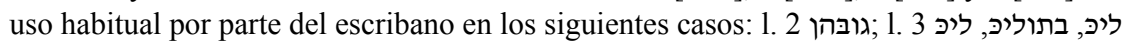

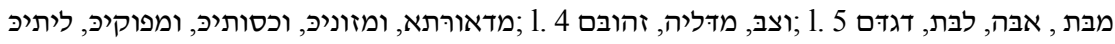

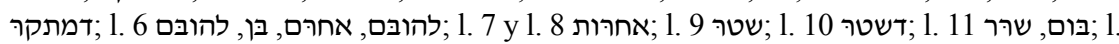

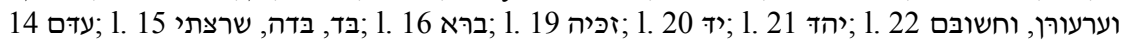

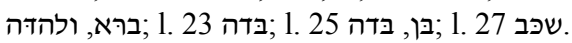

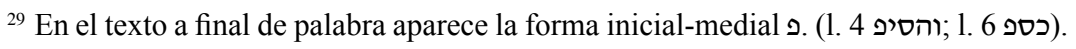
En la transcripción se ha normalizado este uso con ๆ.

${ }^{30}$ Como era preceptivo, la expresión hebrea especifica el valor de la moneda de curso legal válido (יפים), aludiendo en este caso al maravedí (זהובים) y la blanca (לבנות) castellanos.

${ }^{31}$ Nótese la forma gramatical del numeral frente a עשרים אלף.

${ }^{32}$ Heb. חכמינו זיכרם לברכה, 'el recuerdo de nuestros sabios sea para bendición'. 


$$
\text { אבמריה ו' מאביור] }
$$

אנו 14 עדים חתומי מטה כן היה שאמ']ר] לנו ר' אברהם פ'ארו דנן החתן בר היקר הנכבד ר' יעקב פ'ארו נ"ע היו עלי עדים בקנין שלם מעכשיו וכתבו וחתמו עלי בכל לשון של זכות 15 ותנו ביד דוניא אסתר אשתי דא הכלה בת היקר הנכבד ר' יהודהן' ראש ס"ט

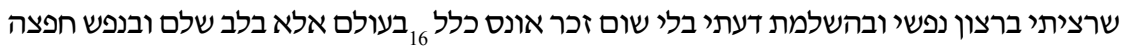
ודעת שלימה ועין יפה וגוף בריא ובביטול ולכל מיני מודעות ומחאות ואונסין שבעולם גלויות

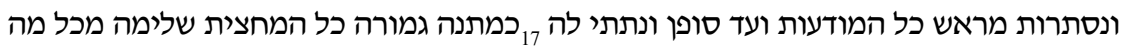

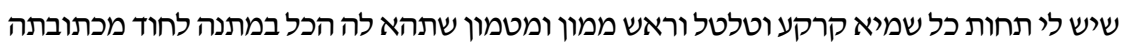

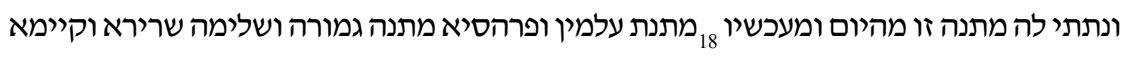

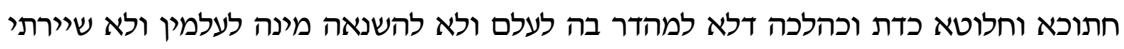

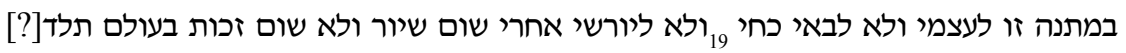

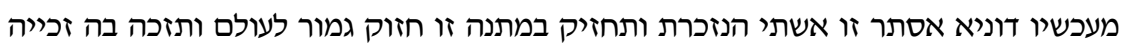

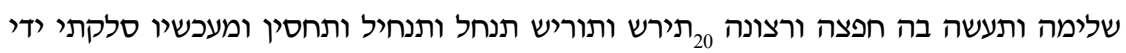

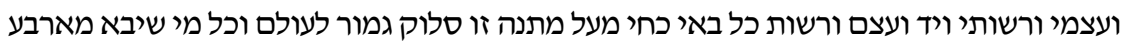

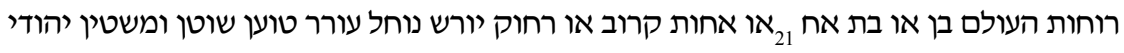
או גואי בכתב או בעל פה ויערער עליה שום ערעור בעולם מחמת מתנה זו יהיו דבריו וערעוריו

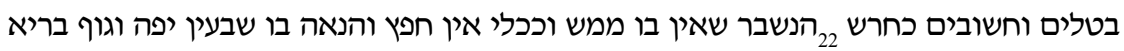

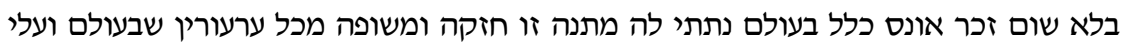

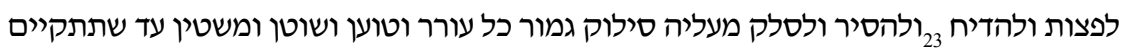

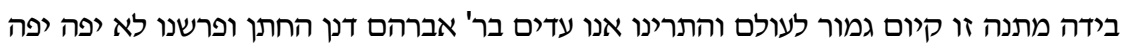

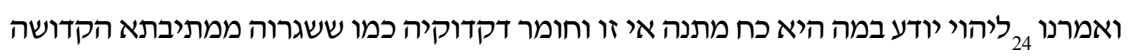

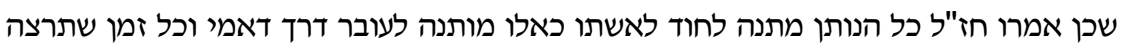

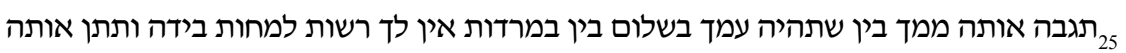

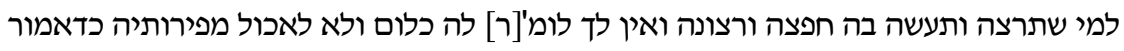

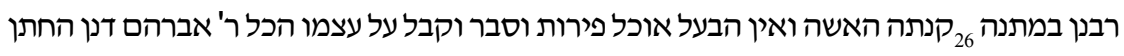

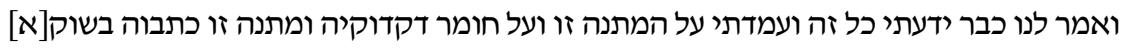

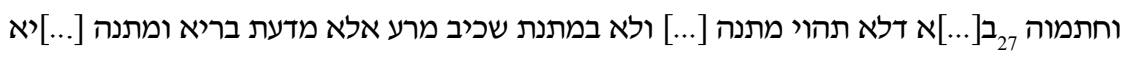

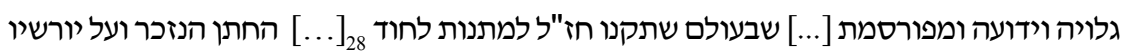

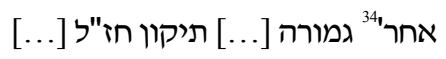

\footnotetext{
${ }^{33}$ Heb. סופו טוב, 'su fin sea para bien'.

${ }^{34}$ Es forma abreviada de אחריות.
} 
El documento se refiere a la escritura de dote y arras de Abraham Faro, hijo de rabí Ya'aqob Faro, ya difunto, y de doña Ester, hija de rabí Yehudá ben Ro’š. El primer párrafo (1. 1-11) corresponde al cuerpo principal de la ketubbá y sigue la estructura habitual de este tipo de textos, que utilizan una mezcla de fórmulas y expresiones en hebreo y arameo. No obstante, resulta llamativo el hecho de que la primera parte esté escrita en escritura semicursiva y no cuadrada, como era habitual; un hecho que se repite, como ya indicara Lacave ${ }^{35}$, en la ketubbá de Torrelobatón. Aunque desconocemos los motivos de esta elección, más aún, en un tipo de documento legal con usos textuales muy formalizados, todo parece indicar que se trató de una práctica más extendida de lo que habitualmente se piensa, al menos, por lo que a las ketubbot castellanas se refiere. El novio, Abraham Faro, aporta un móhar (מוהר) o 'principal' de 200 zuzim que complementa con una toséfet (תוספת) o 'incremento' de 10.000 zehubim en moneda de uso corriente (maravedíes). Por su parte, la familia de la novia aporta como dote o nedunyá (נדוניא) en ajuar y alhajas la cantidad de 10.000 zehubim. La dote se califica expresamente como ș'on barzel, (צאן ברזל) lit. 'rebaño férreo', lo que significa que es inalienable a pesar de que la posesión y gestión de estos bienes corresponden al marido siempre y cuando se garantice la integridad de su devolución si el matrimonio se disolviera. En caso de ganancias o pérdidas, quedarían a cargo del marido. La suma de estas tres cantidades (principal, incremento y dote) ascendió a 22.200 zehubim (maravedíes).

Tanto la ausencia de decoración y sencillez del manuscrito como la cantidad final, notablemente modesta, parecen indicar un estatus socioeconómico medio. El texto principal incluye también una fórmula bastante sencilla de aharayut (אחריות) o 'garantía' por parte del marido, que se compromete a que su esposa reciba el pago de su deuda como acreedora de sus bienes cuando el tiempo lo precise. Esta primera sección concluye con las firmas de dos testigos, dispuestas en líneas independientes (1. 12-13): Šemariá ben Mayor y 'Abraham Yosefón.

En el segundo párrafo (1. 14-28) se desarrolla la sección complementaria del texto principal de la ketubbá, incluyendo la donación completa de la propiedad inmueble del novio a la novia, designada mataná lehud

\footnotetext{
${ }^{35}$ Medieval Ketubot, 29.
} 
(מתנה לחוד), y que comienza en la 1. 17. Mediante fórmulas estereotipadas, el testimonio de esta donación se otorgó en forma de quinyán o juramento completo ${ }^{36}$.

Lamentablemente no se ha conservado el comienzo de la ketubbá, por lo que es imposible conocer el lugar y la fecha exactos en la que fue redactada. En cualquier caso, con los datos indirectos que se recogen en el pleito de referencia y que se analizará más adelante, cabría datarla en la segunda mitad del siglo XV y, muy probablemente, en Valencia de Don Juan. A pesar de que esta villa contó con una importante presencia de población judía $a^{37}$, no se ha logrado identificar a ninguno de los judíos ni familiares citados ni a los testigos que la firman.

\section{b) Aspectos contextuales}

Como ya se ha indicado anteriormente, la presencia de manuscritos hebreos en los pleitos de la Chancillería de Valladolid responde a la necesidad de alguna de las partes pleiteantes de ofrecer pruebas que favorezcan su causa. En este caso, el pleito de referencia en el que se insertó este fragmento de ketubbá procede de la causa iniciada el 11 de julio de 1500 por la judeoconversa María Rodríguez (ol. doña Ester), mujer de Álvaro Rodríguez (ol. Abraham Faro), vecinos de Valencia de Don Juan (León) contra las cofradías de Sancti Spiritus, San Miguel y Santa Marina por deudas que estas instituciones reclamaban a su marido ${ }^{38}$. Como era habitual, la causa llegaba a la Chancillería en segunda instancia, después de

${ }^{36}$ Es fórmula ritual que determina la transferencia de un título de propiedad, una transacción o un compromiso que exige un aval personal o material -simbolizado por un objeto que hace irreversible la translatio- refrendando la lealtad y fidelidad a lo pactado. Sobre este procedimiento, vid. M. Á. Motis DolADER, «Reflexiones en torno al procedimiento civil en los tribunales de Aragón (siglo 15). El aforismo dina de-malkhuta dina», Hispania Judaica Bulletin 7 (2010), 39-100: 49; sobre este tipo de fórmulas en documentación leonesa, vid. J. CAstaÑo, «Los documentos hebreos de León en su contexto pre-notarial», en Judaísmo Hispánico. Estudios en Memoria a José Luis Lacave, ed. E. Romero (Madrid 2002), II, 459-481: 463.

37 Vid. J. Rodríguez Fernández, Las juderías de la provincia de León (León, 1976), 289-319; F. CAntera Burgos, «Juderías medievales de la provincia de León», Archivos Leoneses 55-56 (1974), 85-155.

${ }^{38}$ ARChV, Pleitos Civiles. Zarandona y Balboa (Olvidados), Caja 2490/3. Salvo que se indique lo contrario, todas las referencias que siguen se refieren a este pleito. 
haberse resuelto el pleito en Valencia de Don Juan a favor de estas cofradías mediante ejecución de bienes de varias propiedades del matrimonio (en concreto, una bodega, vasijas de la misma y una casas que poseían en la colación de San Miguel $^{39}$ ), y que finalmente fueron rematadas por 7.000 $\mathrm{mrs}^{40}$. María Rodríguez apeló el embargo de bienes recurriendo a los derechos adquiridos en su ketubbá: como deudora de su dote y arras por una cuantía de 20.000 mrs. pedía que no se hiciera ejecución sobre ningún bien hasta que recuperase la cantidad a la que su marido judío se había obligado. Además, recordaba que esos bienes se habían ganado durante el matrimonio, por lo que la mitad de los mismos eran de su propiedad ${ }^{41}$.

La lectura del pleito ofrece también interesantes noticias sobre las nuevas condiciones de vida de estos judíos convertidos regresados del exilio pocos años después de la Expulsión, sus redes familiares así como

${ }^{39}$ Las casas se ubicaban limítrofes «de la vna parte con casas e corral de Diego de León e de la otra parte, casas e corral de Bernaldo Fernández e calle de conçejo» (fol. 11v). En el proceso se incorporan también las cartas de venta de estas casas y otras propiedades que el matrimonio compró pocos años después de su conversión. El 6 de abril de 1497 Álvaro de Ordás e Isabel Magarrón, vendieron a Álvaro Rodríguez y a su mujer una viña en el término de El Palomar por 250 mrs (fol. 30r). El 11 de abril de 1494, López Díaz de Medrano, contador del Conde de Valencia de Don Juan, y su hijo, vendieron al matrimonio la casa que se les había embargado por $6.500 \mathrm{mrs}$ (fol. 32r).

${ }^{40}$ Fol. 22r.

${ }^{41}$ Fol. 2r: «E allegando de mi justicia e derecho contra vna aserta entrega e seruiçio que avéys mandado fazer en vna bodega e çierta vasyja e lo rematastes en mi prejuyzio [...] e agora es venido a mi notiçia que avéys mandado fazer otra hexecuçión en otra casa en que yo viuo a pedimiento de Juan Pérez e de Sancho de León, abades de Santi Spiritus, e de Martín y Juan, abades de San Miguel, e de Matabueys, abad de Santa Marina, por çierta quantía de mrs. que se dize dever el dicho mi marido a las dichas cofradías [...] digo que la dicha entrega e seruiçio ni los remates [...] no valió [...] e que todo lo devéys reponer en el atestado que estava antes e al tiempo que mandastes fazer la dicha entrega e execuçión e que lo devéys revocar por lo que se sigue: [...] el dicho Áluaro Rodrígues serme obligado a veynte mill $\mathrm{mrs}$. de dote que reçebió quando con él casé e todos sus bienes me fueron e[roto] obligados a la dicha quantía de mrs. e fasta que yo sea entrega[da] e pagada de los dichos veynte mill mrs. non podéys ni devéys mandar fazer la dicha aserta entrega e execuçión, como mi debda sea primera en tiempo e preuiligiada, quanto más que la dicha esecuçión no avía lugar en los dichos byenes quanto a la mi mitad de casas e vasyja, pues es çierto la meytad dello ser mío, pues que se adquirió e ganó durante nuestro matrimonio [...]. Por ende, vos pido e requiero que fasta en tanto que yo sea entrega e pagada real e fetualmente de dicha dote e mrs. non proçedades en la dicha aserta esecuçión e mandéys sobreser enella». 
el reciclado y reutilización de esta ketubbá como soporte de encuadernación. A petición de Álvaro Rodríguez el 25 de junio de 1500 se realizó un testimonio notarial ante el escribano y notario Pero González de Villanueva, vecino de Villamañán (León) con el objeto de identificar a los testigos que firmaron la ketubbá. Los testigos presentados fueron Ángel Rodríguez, vecino de Villamañán (León) y Rodrigo Álvarez, vecino de Gordoncillo (León). Ante la ketubbá, el primero reconoció la firma de su padre judío, don Semariá Abén Mayor. El segundo, declaró que se trataba de su firma cuando era judío y tenía por nombre Abraham Yuçefón ${ }^{42}$. En otro testimonio notarial del 27 de junio de ese mismo año y ante el mismo notario, García Rodríguez, vecino de Villamañán testificaba lo siguiente:

Visto la dicha escritura judiega en el dicho libro donde estaua cosyda en lo que se podía leer /dixo/ que hera carta de dote que dizían mataná que fablaua de veynte mill mrs. que Yudá Abenrrós daua en casamiento a Yçer [sic], su fija, con el dicho Áluaro Rodrigues que se llamaua entonçes Abraham Faro ${ }^{43}$.

En el pleito presentó su demanda el hijo del matrimonio, probablemente ya converso de segunda generación: Cristóbal Rodríguez, también vecino de Villamañán. Mediante requerimiento del 23 de febrero de 1501, pedía al escribano Pero González de Villanueva la entrega del pergamino original de la «carta de dote y casamiento» de su madre con el fin de aportarla en la Chancillería y que este había reutilizado como encuadernación tras la expulsión de los judíos:

Notario, dármeys por testimonio signado a mí, Christóval Rodrigues [...] fijo de Aluaro Rodrigues, vecino de la villa de Valençia e de su muger, María Rodrigues, en cómo dego [sic] González de Villanueva, escribano en esta villa, que bien sabe cómo por ante él fueron presentados çiertos recabdos de escrituras que están en ebrayco, que es un dote e casamiento que fue de la dicha María Rodrigues, mi madre, el qual dote sobre çierto pleito e debate que tray la dicha mi madre en Valladolid [...] le es pedido que lo lieve e presente [...] que le pido por mí y en nombre de la dicha mi madre [...] que me dé y entregue el dicho dote oreginal [...]. E el dicho Pero Gonsales

\footnotetext{
${ }^{42}$ Fol. 1r.

${ }^{43}$ Fol. 1v.
} 
dixo que ya estas escripturas que demanda hera vna mataná escripta en judiego ${ }^{44}$ que fuera presentada ante él contra [quando eran] judíos e después que se fueron destos reynos pensan[do] que nunca avían de venir, que la cortara e la posiera por [co]bertero de vn libro e después que venieron el año pa[sa]do de quinientos años, que el dicho Áluaro Rodrigues e su muger demandaron signado aquello que se podía leer e trax[e]ron los testigos de quien estava firmada la dicha escrip[tu]ra e leyeron todo lo que pudo leer e juraron que aquello era verdad que en ella se contenía e que ellos fueron testigos della e la firmaron de sus nombres e que aquellos [e]ran los sus nombres propios que enella estavan $[\ldots]^{45}$.

Finalmente, el 6 de marzo de 1501 el procurador de María Rodríguez, Pedro de Arriola, hacía presentación del pergamino original acompañado de su traducción al romance castellano realizada por dos cristianos nuevos, cuyos nombres no se especifican en la notificación y petición del traslado, pero sí al final del mismo, siendo estos el bachiller de la Torre y Luis Zurcidor: ${ }^{46}$

Este es el traslado de una carta de arras e dote sacado de lengua abrayca en nuestra lengua castellana. Comiença: ' ${ }_{1}$ Abraham Faro, fijo del honrrado rabí Jacó Faro, defunto, dixo a esta doña Ester, esta novia virgen, fija del honrrado rabí Udá Abenrós: Sé mi muger como ley de Muysén ${ }_{2}$ y de Ysrrael e yo, con ayuda de Dios, seruiré e honrraré e manterné e daré de vestir a la ley de los varones judíos que siruen e honrran e visten e mantienen a sus mugeres con verdad y daré ${ }_{3}$ a ti presçio de tu virginidad dozientos reales de plata que te pertenesçen de ley y tu mantenimiento y tu vestido y lo que ovieres de menester como vso de toda la tierra. Y consentió doña Ester, esta nouia, de ser su muger. ${ }_{4} \mathrm{Y}$ consentió rabí Abrahán, el nouio susodicho. E añadiola de lo suyo del sobre el casamiento della diez mill maravedíes blancos de dos blancas viejas cada vn maravedí dados por donaçión. Y la hazienda que traxo ${ }_{5}$ doña Ester de casa de su padre a casa de su marido susodicho en paños e en joyas y en ropas de cama y en todas cosas que bienes se pueden dezir ${ }_{6}$ sumó diez mil ma-

\footnotetext{
${ }^{44}$ Nótese el uso metonímico de mataná por ketubbá.

${ }^{45}$ Fols. 23r-v. El 2 de marzo de ese mismo año, el procurador de María Rodríguez, Pedro de Arriola, pidió también carta de provisión con el mismo objetivo (fol. 21r).

${ }^{46}$ En la traducción se han indicado mediante subíndices las líneas correspondientes al texto hebreo transcrito.
} 
ravedíes de la dicha moneda, de manera que suma todo entre lo qual la dio e lo que ella traxo veynte mill maravedíes de la dicha moneda ${ }_{7}$ y dozientos reales más. Se otorgó e se obligó el novio rabí Abrahán y dixo asý: 'Que qualquier $\operatorname{ar}[r]$ isque ${ }^{47}$ y costas desta escriptura y lo quél añadió de lo suyo propio y lo que la dicha su muger truxo todo lo reçibo sobre mí e sobre mis herederos e sobre todos mis bienes como bienes de ovejas de yerro, que si sobraren, ${ }_{8}$ sobren para mí y, si faltaren, falten por mí. E yo tomo el cargo e me obligo por todo lo mejor de bienes e conpras que yo tenga o aya en ellos posesión o arrisque y en los que no tengo arisque para que todos sean obligados y fiadores y súbditos a ${ }_{9}$ esta escriptura e a lo que yo le acresçente e a lo que mi muger traxo para pagarse dellos complida paga y quando otros bienes no oviesen de la ropa que acuestes traygo en vida y en muerte fuerte e firme obligaçión segund la fuerça que tienen e suelen tener las cartas e acreçentamientos de los [vestidos $]^{48}$ y joyas que las mugeres trahen consigo que se vsan en las fijas de Ysrael, ${ }_{10}$ obligué comigo quatro pasos de suelo como hordenança de los dotores syn aver fraude nin syn tener treslado de otra carta contra desta. Y tomamos obligaçión al dicho novio por la dicha doña Ester, obligaçión ${ }_{11}$ fuerte e firme con ynstrumento vastante para obligarse con él. Y todo quedó segund el vso e hordenança que por condiçión pusyeron entre ellos los dichos novios. Y cumplyóse todo en el dicho día y todo es firme y recto'.

Están firmados en esta escritura dos nombres quel vno dize Semariá Avén Mayor y en el otro Abrahan Yoçefón. Rúbricas: El bachiller de la Torre, Dionisius Bachalarius ${ }^{49}$. Luis Çurzidor ${ }^{50}$.

${ }^{47}$ E. d., 'riesgo', Real Academia Española, Banco de datos (CORDE) [en línea]. Corpus diacrónico del español. $<\mathrm{http} / / / \mathrm{www}$. rae.es $>$ [01/02/2014].

${ }^{48} \mathrm{La}$ lectura es dudosa. El texto hebreo en este punto se refiere a la dote o nedunyá.

${ }^{49}$ La firma del Bachiller de la Torre tiene rasgos caligráficos muy similares al texto traducido, por lo que me inclino a pensar que fue escrito por su mano. Aunque aparentemente se distinguen tres firmas, considero que el nombre y título latinizado Dionisius Bachalarius corresponde al del bachiller de la Torre.

${ }^{50}$ Fol. 29r. 


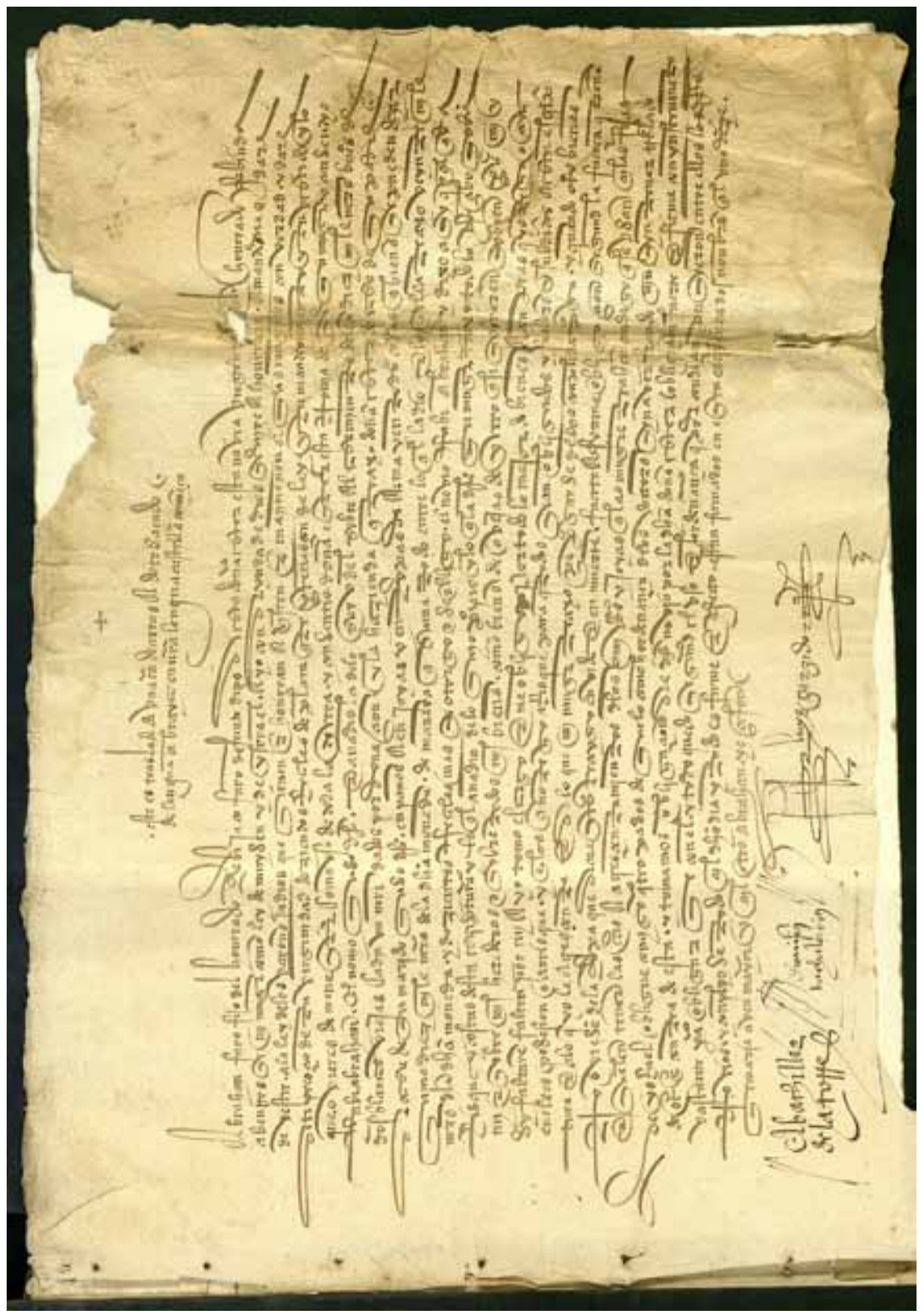

Fig. 3. Traslado romance de la Ketubbá de Valencia de Don Juan. (C) ARChV, Pleitos Civiles. Zarandona y Balboa (Olvidados), Caja 2490/3, fol. $27 \mathrm{r}$. 
La traducción del texto hebreo-arameo reproduce solo la sección principal de la ketubbá, pero no la segunda parte de las condiciones establecidas. Esta primera sección era la que otorgaba valor jurídico y especificaba las cláusulas generales y aportaciones económicas incluidas en el contrato matrimonial por lo que, al parecer, los traductores no consideraron necesario traducir todo el pergamino. Es un traslado bastante literal que recoge con exactitud el contenido del original, adaptándolo al estilo de la sintaxis y usos léxicos del romance castellano de la época. Fue una práctica habitual el recurrir a población conversa, ya que tan solo los más formados podían tener un conocimiento suficiente de las complejas fórmulas hebreas y arameas de este tipo de documentos. La ketubbá de Torrelobatón también fue traducida, aunque no se precisa el nombre de sus autores ${ }^{51}$. En algunas ocasiones, se ha conservado tan solo la traducción romance, como en el caso de la ketubbá de Trijueque (Guadalajara), cuyo traslado fue encargado a Alfonso de Zamora, profesor de Hebreo y Caldeo en la Universidad de Alcalá y colaborador de la Biblia Políglota Complutense ${ }^{52}$. En este caso, sería interesante profundizar más en cuál pudo ser el procedimiento seguido por la Chancillería a la hora de encargar estas traducciones; cómo lograron contactar con conversos, quién proponía sus nombres y si contaba con un número establecido de colaboradores que se prestaran habitualmente a ello. Pero la ausencia de noticias no permite ir más allá de lo señalado. El proceso incompleto se interrumpe el 11 de mayo de 1501, cuando las partes litigantes son recibidas a prueba, por lo que tampoco sabemos si finalmente la demanda de María Rodríguez logró su fin.

\subsection{Ketubbá de Villadiego (Burgos)}

Esta ketubbá completa $(600 \times 270 \mathrm{~mm})^{53}$, en tinta negra-sepia y en estado muy deteriorado a pesar de haber sido restaurada hace pocos años, se extrajo del pleito de Hidalguía iniciado en 1549 por Sancho

${ }^{51}$ Publicada por RePResa, «Una carta de esponsales y otras prescripciones», 38-39 y reproducida de nuevo, junto a la reconstrucción del texto hebreo por LACAVE, Medieval Ketubot, 249-251.

52 Vid. F. CAntera Burgos, «La Ketuba de D. Davidovitch y las Kĕtubbot españolas», Sefarad 33 (1973), 375-386: 385.

${ }^{53}$ ARChV, Pergaminos, Carpeta 28/26. 
Tabares, vecino de Amusco (Palencia) ${ }^{54}$. Tras la lectura pormenorizada de las ocho piezas de las que consta, puede concluirse que, en este caso, el documento no tiene ninguna conexión con el contenido del pleito. El pergamino presenta roturas en ambos márgenes y en el centro de su sección inferior, con marcas de dobleces y tinta muy desvaída, a pesar de que la parte que incluye el texto parece haberse conservado como parte interior. La parte del pelo (folio vuelto) presenta marcas de encuadernación con dobleces adaptados a un libro de tamaño aproximado de cuarto de pliego y contiene algunas anotaciones en cuenta castellana, apenas legibles.

La ketubbá está escrita con dos tipos de grafía hebrea y se estructura en cuatro párrafos. El primero, en escritura cuadrada muy cuidada, y el resto, en semicursiva sefardí (probablemente del siglo XV). En el preámbulo se utiliza una escritura cuadrada de mayor tamaño. Aparentemente no se observan motivos decorativos, salvo dos ornamentos en la sección superior izquierda del preámbulo; en sentido vertical y margen izquierdo aparece también una anotación numérica (XLXXIIII).

Debido al mal estado del pergamino y calidad de la tinta, no he podido realizar una transcripción íntegra del texto. No obstante, reproduzco a continuación su sección principal, cuya escritura cuadrada es la que con mayor claridad se puede leer, así como la reconstrucción parcial del resto de párrafos. La ketubbá está compuesta de 37 líneas, incluido el preámbulo. La sección principal abarca las líneas 2-19 y se distribuye en dos párrafos separados por un amplio espacio blanco y por el uso de escritura semicursiva a partir de la línea 11. El tercer párrafo abarca las líneas 2128 y el cuarto, las líneas 29-37. Entre el segundo, tercero y cuarto párrafos se incluyen varias firmas.

${ }^{54}$ ARChV, Sala de Hijosdalgo, Caja 96/9. Hijo de Diego de Tavares, difunto, y de María López de Losa, viuda, Sancho de Tavares inicia a los setenta años pleito de hidalguía en la Chancillería de Valladolid. En primera instancia fue resuelto a favor del Concejo, y en apelación, a favor del demandante. Además de otra documentación, se incorporó a la prueba un padrón de la villa de Amusco de 1502 (ARChV, Protocolos y Padrones, caja 58/1). 


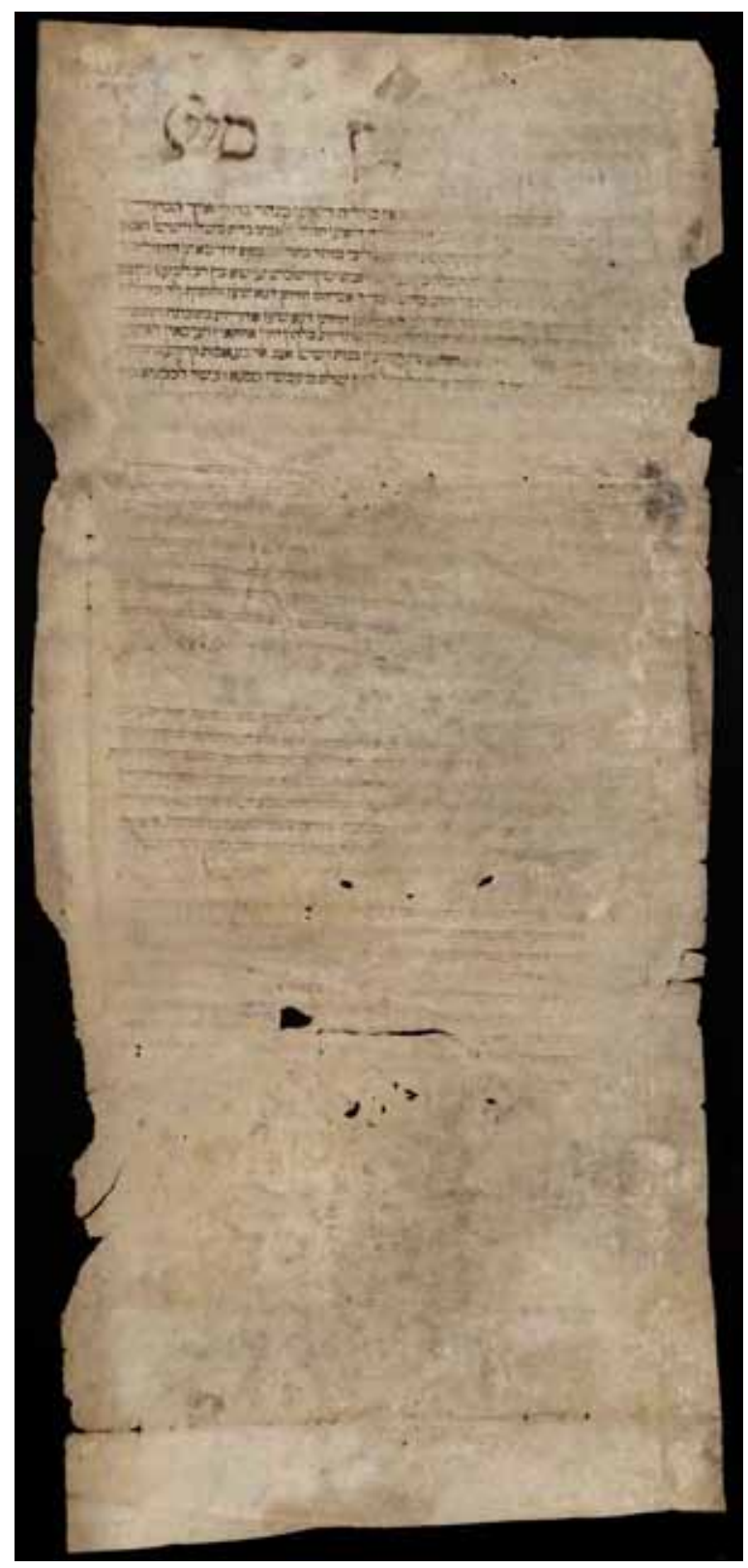

Fig. 4. Ketubbá, ¿s. XV? Villadiego (Burgos). (C) ARChV, Pergaminos, Carpeta 28/26. 


$$
5\left[\begin{array}{l}
55 \\
5
\end{array}\right.
$$

[לברי]את [עו]לם למנין שאנו [מונין בו] בכאן בויליהדיאיגו מנהר ברולי'ש איך הבחור

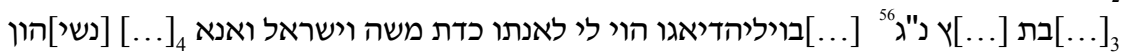

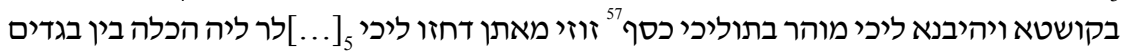

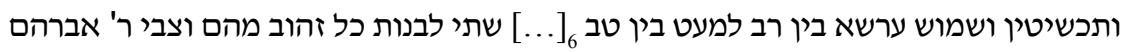

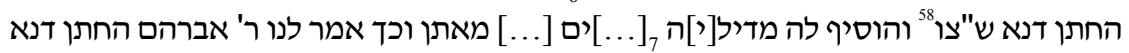

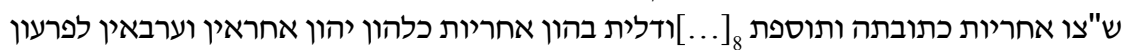

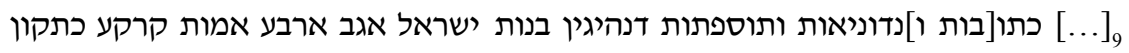

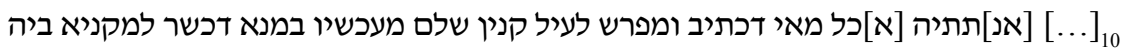

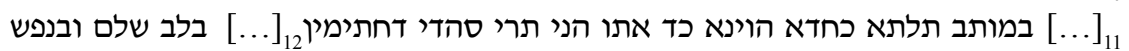

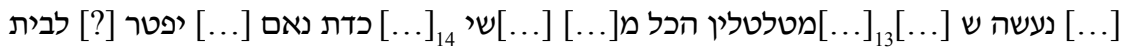

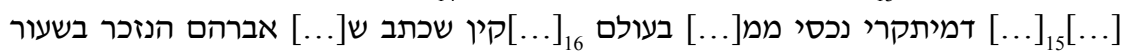

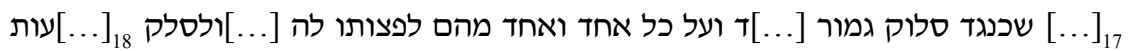
שבעולם גלויות וסתורות ומודעין [...]

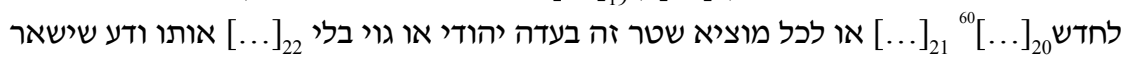

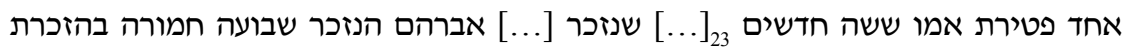

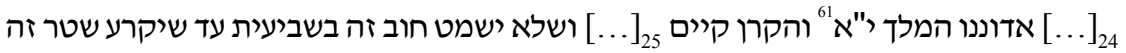
[....] בכל עסק שטר זה ובגבייתו]?] בשבועה הנזכרת נאמנות [.....

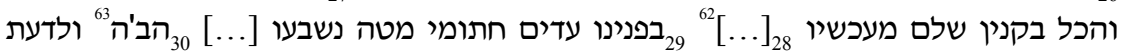

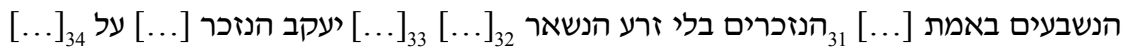

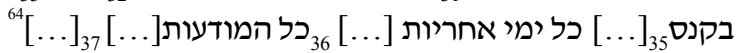

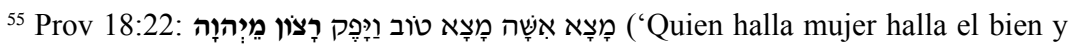
un favor ha obtenido de Adonay'). Este mismo preámbulo se encuentra en la ketubbá de Borja, Tudela 1 y Tudela 2, vid. Lacave, Medieval Ketubot, 211, 217 y 237. En la última palabra, el nombre de Dios se indica, según la tradición sefardí, con tres yodes. El otro rasgo que aparece es meramente ornamental.

${ }^{56}$ Vid. nota 27.

${ }^{57}$ A diferencia de la ketubbá anterior, se mantienen las formas finales.

${ }^{58}$ Heb. שמרו צורו וגואלו, 'Que Dios lo proteja'.

${ }^{59}$ Con metátesis. Léase תשערז. La fecha está incompleta.

${ }^{60} \mathrm{Al}$ menos, tres firmas ilegibles.

${ }^{61}$ Heb. ישמרהו אל, 'Dios lo guarde'.

${ }^{62}$ En esta línea aparecen cuatro firmas ilegibles. Es posible que los testigos sean los mismos de antes.

${ }^{63}$ Heb. הקדוש ברוך הוא, 'El Santo, bendito sea'.

${ }^{64}$ En esta última línea apenas se distinguen los rasgos de una firma. 
El texto conservado no proporciona la fecha del casamiento completa (19 de un mes y año indeterminados, 1. 19), pero sí el lugar. Procede de la villa burgalesa de Villadiego (1. 2: ויליה דיאיגו), que es atravesada por el río Brullés (1. 2: ברולי'). Villadiego, al norte de la provincia de Burgos, contaba con una próspera aljama bajo el dominio de los Velasco a finales del siglo XV. Con sinagoga posteriormente convertida en iglesia de San Miguel, apenas conocemos algunos nombres judíos ${ }^{65}$. Ninguno de ellos puede identificarse con el del novio, Abraham (1. 6: אברהם). Desconocemos su filiación familiar y el nombre de la novia; tampoco la cantidad aportada por ambos, salvo los 200 zuzim estipulados como móhar. La fórmula de aharayut o 'garantía' (1. 12-20) incluye tres firmas de testigos judíos. La ketubbá fue autentificada y los testigos validados por miembros del tribunal rabínico o bet din (1. 11). En los dos últimos párrafos (1. 21-37), muy incompletos, se especifican algunas de las condiciones del contrato o tena'im (תנאים). Conforme a la ley judía, la deuda contraída no podría ser cancelada al séptimo año (̌̌emițá $)^{66}$ y sería válida hasta que el šetar o garantía de instrumento sea destruido (1. 25). El marido garantizaba solemnemente el cumplimiento de todas sus obligaciones económicas que había contraído con su mujer en forma de quinyán o compromiso bajo juramento completo.

Recibido: 28/02/2014

Aceptado: 23/10/2014

${ }^{65}$ Vid. I. CAdIÑAnos BARDECI, Judios y mudéjares en la provincia de Burgos (Burgos, 2011), 277-281; L. Huidobro Serna, «Contribución a la historia de los hebreos en la diócesis y provincia de Burgos», Boletín de la Comisión Provincial de Monumentos Históricos y Artísticos de Burgos 42-43 (1933), 397-405 y 425-431.

${ }^{66}$ De 15:1-2 y 31:10. Según Maimónides, Misné Torá, Hilkot Šemiṭá 9, halakot 3-4, el año sabático no anulaba deudas hasta su conclusión. 